Article

\title{
The Empirical Measurement of a Theoretical Concept: Tracing Social Exclusion among Racial Minority and Migrant Groups in Canada
}

\author{
Luann Good Gingrich ${ }^{1, *}$ and Naomi Lightman ${ }^{2}$ \\ ${ }^{1}$ School of Social Work, York University, Toronto, ON M3J 1P3, Canada; E-Mail: luanngg@yorku.ca; \\ Tel.: +1-416-736-2100 \\ ${ }^{2}$ Ontario Institute for Studies in Education, University of Toronto, Toronto, ON M5S 2J7, Canada; \\ E-Mail: naomi.lightman@mail.utoronto.ca; Tel.: +1-647-865-6543 \\ * Corresponding author
}

Submitted: 23 July 2014 | In Revised Form: 6 November 2014 | Accepted: 6 November 2014 |

Published: 24 July 2015

\begin{abstract}
This paper provides an in-depth description and case application of a conceptual model of social exclusion: aiming to advance existing knowledge on how to conceive of and identify this complex idea, evaluate the methodologies used to measure it, and reconsider what is understood about its social realities toward a meaningful and measurable conception of social inclusion. Drawing on Pierre Bourdieu's conceptual tools of social fields and systems of capital, our research posits and applies a theoretical framework that permits the measurement of social exclusion as dynamic, social, relational, and material. We begin with a brief review of existing social exclusion research literature, and specifically examine the difficulties and benefits inherent in quantitatively operationalizing a necessarily multifarious theoretical concept. We then introduce our conceptual model of social exclusion and inclusion, which is built on measurable constructs. Using our ongoing program of research as a case study, we briefly present our approach to the quantitative operationalization of social exclusion using secondary data analysis in the Canadian context. Through the development of an Economic Exclusion Index, we demonstrate how our statistical and theoretical analyses evidence intersecting processes of social exclusion which produce consequential gaps and uneven trajectories for migrant individuals and groups compared with Canadian-born, and racial minority groups versus white individuals. To conclude, we consider some methodological implications to advance the empirical measurement of social inclusion.
\end{abstract}

\section{Keywords}

Canada; methodology; secondary data analysis; social exclusion; social inclusion; Survey of Labour and Income Dynamics

\section{Issue}

This article is part of the special issue "Indicators and Measurement of Social Inclusion", edited by Professor Peter Huxley (Bangor University, UK).

(C) 2015 by the authors; licensee Cogitatio (Lisbon, Portugal). This article is licensed under a Creative Commons Attribution 4.0 International License (CC BY).

\section{Introduction}

The concepts of social exclusion and inclusion (SE/I), according to noted economist Amartya Sen (2000), have potential to "substantially help in the causal as well as constitutive analyses of poverty and deprivation" (p. 47). Yet in their application, the ideas of SE/I often lose their distinctive complexity. For example, it is common in research and policy literatures for social exclusion to be operationalized as a tally of people who lack secure attachments to the labour market, or whose incomes fall below a certain threshold (e.g., Esping-Andersen, Gallie, Hemerijck, \& Myles, 2001; Roche, 2000). This "categorical point-of-view" (Good Gingrich, 2003), reflected in the highly criticized policies of the Social Exclusion Unit in the United Kingdom, 
falls short due to its conservative and conserving emphasis on individual interventions to address largescale social inequalities (Byrne, 2005; MacLeavy, 2008). However, given growing disparities both among and within nations, the need to move SE/I theory from ideas to indicators is urgent, as "what we measure shapes what we collectively strive to pursue-and what we pursue determines what we measure" (Stiglitz et al., 2009, p. 9).

Social exclusion scholars observe that its counterpart-social inclusion-is widely adopted as an indisputable social value and an inspired direction for social policy and human services. Social inclusion is often equated with participation in various social arenas, and interventions focus on increasing individual capacity for incorporation or integration. This ideal of social inclusion implies a "centre" or series of "centres" (Room, 1999; Sin \& Chung Yan, 2003) that is inherently and universally beneficial, and mandatory insertion or voluntary engagement in this centre moves an individual from social exclusion to inclusion. In employmentbased social welfare systems, for example, social inclusion is assumed to be achieved through paid work (Lightman, 2003). Yet an abundance of research shows that meaningful inclusion is not available for everyone through participation in the labour market, access to social services, or engagement in mainstream society, as these structures and social relations are exclusionary by design (Good Gingrich, 2006; Walcott, 2014). Some have argued that the best that is offered marginalized individuals and groups through insertion or participation in these centres is "unfavourable inclusion" (Sen, 2000) or "subordinate and disadvantaged insertion" (Munck, 2005). Thus, if social inclusion is to provide an innovative focus for tackling stubborn social problems, the empirical analysis of SE/I must examine the nature of the margins and the core (structures), as well as movement and relative positions in relation to them (dynamics). The primary objective of this article is to present an approach for using secondary data to develop measures of SE/I that can be applied beyond our case examples.

We begin with a brief review of existing empirical measures of social exclusion. Subsequently, we posit a conceptual model of SE/I that forms the basis of our indicators and statistical analyses. We then report on our empirical application of this conceptual model in three recent studies in which we used secondary data analysis of the Survey of Labour and Income Dynamics (SLID), a national Canadian dataset. Specifically, we analysed labour market outcomes and trajectories of individuals and groups to demonstrate intersecting forms of social exclusion in Canada's labour market from 1996-2010. With our analytical priority on social structures and dynamics, our objective here is primarily descriptive rather than predictive or explanatory. Notably, we find racial minority status, along with immigrant status, to operate as defining social attributes in the dispossession and devaluation of material and symbolic forms of personal assets and in the production of social divides. Finally, drawing lessons learned from our own quantitative research and the literature, we conclude by proposing some directions for future research that is focused on further refining indicators and approaches for the measurement of social exclusion to inform social policies and services that effectively advance social inclusion.

\section{Background Literature: Existing Measures of Social Exclusion and Inclusion}

The majority of existing research on social exclusion is conceptual or qualitative in nature. Such studies provide rich narratives and powerful metaphors to document the compounding and cumulative effects of material and social deprivation, or the "double jeopardy" and "double binds" of social exclusion that reach well beyond simplistic measures of income and wealth (Good Gingrich, 2008, 2012). Within the theoretical literature, there is general consensus that the concept of social exclusion is characterized by the following distinctive features: it is multidimensional; dynamic; occurring in a particular time and place; relative (or comparative); structural, rather than individual, in its sources; relational, having to do with social processes; and its effects are interconnected and compounding (Farrington, 2001; Hyman, Mercado, Galabuzi, \& Patychuk, 2011). From this research, it is clear that the ideas of social exclusion and inclusion point toward the complexities of the social world, and are thus used to refer to a wide variety of social and personal ills.

Over the past two decades, researchers have begun to quantitatively operationalize social exclusion. Early efforts relied heavily on familiar and well-used constructs, such as personal or household income and consumption below a poverty line (e.g., Giorgi \& Pohoryles, 1999; Tibaijuka \& Kaijage, 1995); intra- and international comparisons of uneven income distribution (see, for example, Glennerster, 2000; Stierle, Kaddar, Tchicaya, \& Schmidt-Ehry, 1999); insecure labour market attachment (Esping-Andersen et al., 2001; European Commission, 1994); and substandard housing and homelessness (Ginsburg, 1997; Hobcraft, 2000).

Most recent studies operationalizing social exclusion in quantifiable terms use a combination of material and social indicators, thus emphasizing its multidimensional nature (e.g. Levitas et al., 2007; Nolan \& Whelan, 2010; Pirani, 2013). While a few researchers focus solely on economic indicators (thus resembling poverty measures) for national or multi-national comparisons (Aldridge, Kenway, Maclnnes, \& Parekh, 2012; Lechman, 2013), others add subjective measures of social supports and civic involvement to objective conditions such as unemployment and dependency on wel- 
fare benefits (Atkinson, 2000; Perri 6, 1996; Spoor, 2013). In Canada, Renahy, Alvarado-Llano, Koh and Quesnel-Vallée (2012) use the National Household Survey Pilot (2008) for a cross-sectional analysis of economic exclusion (as a subjective measure of material deprivation), income and health in four provinces. With a similar emphasis on multidimensional outcomes, Atkinson, Catillon, Marlier and Nolan (2002) propose a list of indicators and a process by which these measures can develop Europe's social agenda. As is common in this literature, Atkinson et al. (2002) do not provide definitions or a theoretical framework for "social exclusion" or "social inclusion", but rather "simply accept here the use of the terms as shorthand for a range of concerns considered to be important in setting the European social agenda" (p. 3).

Informed by the considerable refinement and increasing precision of quantitative measures of social exclusion that has occurred in recent decades, our research aims to make several unique contributions to this literature. First, the vast majority of research that attempts to measure social exclusion pertains to the European context, making it problematic for application in other regions of the world. Working in the Canadian context, we utilize a rich national dataset for our analyses. Second, the bulk of existing research focuses on static outcomes of discrete dimensions (e.g., Koti, 2010; Walker \& Vajjhala, 2009), thus losing sight of the processes of social exclusion. ${ }^{1}$ We exploit longitudinal data in our effort to trace social dynamics that function to keep people stuck in place. Third, perhaps corroborating claims that social exclusion language was "adopted to depoliticize poverty as far as income redistribution was concerned" (Veit-Wilson, 1998, p. 97), non-economic indicators are often limited to subjective experiences and self-reports (Hyman, Meinhard, \& Shields, 2011; Michalos et al., 2011), minimizing the everyday/everynight realities (Smith, 1990) of social exclusion that we argue are ultimately material in consequence. Our concern is not the psychological experience (or feelings) of social exclusion apart and separate from the material realities, but rather our indicators are geared toward measuring intersections between individual subjective experience and structural material realities. Finally, in order to preserve the relative and relational qualities of the concept of social exclusion, we distinguished between individual attributes (such as race/ethnicity, sex, and birthplace) and acquired capital or symbolic assets (such as education, credentials, or language skills) to elucidate the social structures and processes that work to make groups and order society.

\footnotetext{
${ }^{1}$ One notable exception is a life-course analysis of social exclusion using an unusual longitudinal database in Sweden following individuals from birth to 48 years of age (Bäckman \& Nilsson, 2011).
}

\section{Theoretical Framework: A Conceptual Model of Social Exclusion}

Our working definition of social exclusion is as follows: The official procedures and everyday practices that function to produce, fortify, and justify economic, spatial, socio-political, and subjective divides (Lightman \& Good Gingrich, 2012). Processes of social inclusion, then, must move groups and societies toward the reconciliation of those divides.

Good Gingrich's (2006) conceptual model of SE/I is built on measurable concepts or indicators, and is designed to analyse the dynamics that work to strip individuals and groups of the various types of capital they possess. From this theoretical vantage point, social exclusion signifies a precise set of social processes that denies effective exchange of one's holdings - or capability (Sen, 2000)-and thus cuts off avenues for upward mobility. Thus, social exclusion-and inclusionhas to do with access to all sorts of available resources; but more importantly, outcomes are secured through processes that open or close access to legitimate means of accumulating and converting capital from subordinate social positions. The crucial mechanism through which the four forms of social exclusion are realized-economic, spatial, socio-political, and subjective-is the dispossession and devaluation of all types of capital in everyday social life.

According to sociologist Pierre Bourdieu, the social world is made up of multiple and diverse social fields and sub-fields, or arenas of contest and struggle (Bourdieu, 1990). A social field, analogous to a field of play in a highly competitive game of sport, is defined by its own system of capital, both material and symbolic, as individuals and groups compete for social and material goods that are effective and valued in that social field. The system of capital operates much like the rules of the game-the specific "perceptions, appreciations, and actions" (Bourdieu, 1977, p. 261) that account for the means by which individuals get ahead, or fall behind; the taken-for-granted logic and beliefs that determine the distribution and worth of all available resources in a social field, including those that are economic, and those that need to be converted to have material value. In our research, we understand Canada's labour market to constitute a sub-field within the broader market-state social field that functions according to a precise and familiar system of values or laws-such as "self-interested calculation and unfettered competition for profit" and the "conservative glorification of individual responsibility" (Bourdieu, 2005, pp. 7, 11)-to reproduce its social organization.

Bourdieu defines three primary and broad species of capital, or "the energy of social physics" (Bourdieu, 1990, p. 122) that provide the basic working elements 
of social exclusion. ${ }^{2}$ These types of capital, which are circulated and reproduced in everyday social relations and practices, are economic, social, and cultural. Building on Bourdieu's concepts, the intersecting four forms of social exclusion that we identify correspond with the composition and capacity (or symbolic power) of economic, social, and cultural capital held by and accessible to individuals and groups. Specifically, economic exclusion, associated with the dispossession of economic capital, can be represented by waged and non-waged income, employment variables, and measures of wealth or personal property. In Canada, economic gaps show up in disparate levels of income (Block, 2010; Couturier \& Schepper, 2010), earnings (Elrick \& Lightman, 2014; Frenette \& Morissette, 2003; Yalnizyan, 2007), wealth (Osberg, 2008; Zhang, 2003), housing conditions (Johnston, 2013; Kim \& Boyd, 2009), and affordability of basic necessities (Kerstetter, 2009; Lightman, Herd, \& Mitchell, 2008). Social exclusion also works to deny and devalue economic and social capital to produce spatial exclusion, concentrating disadvantage that may or may not be associated with low levels of income, and is manifested when whole regions and communities experience abnormally high rates of poor health, infant mortality, and overall poor wellbeing (Ades, Apparicio, \& Séguin, 2012; Gilbert, Auger, Wilkins, \& Kramer, 2013); lack of available social resources, infrastructure, jobs, and political involvement (Zhao et al., 2010); and even low levels of subjective sense of belonging and trust (Reitz, Banerjee, Phan, \& Thompson, 2009).

Socio-political exclusion has to do with the dispossession and devaluation of social and cultural capital, or the denial of social recognition and legitimacy in civic processes, laws and policies, and everyday interactions. Its outcomes can be evaluated in part through access to social benefits and health services, educational activities and credentials, occupational status and secure employment (apart from monetary measures), and recognized positions in public arenas (Fuller \& Vosko, 2008; Raphael, 2010; Reitz \& Verma, 2004; Wilson et al., 2009). Socio-political exclusion is also apparent in the absence of representation in official discourse and documentation. For example, it is well known that the most marginal in many societies - such as First Nations peoples, temporary residents, and unpaid workers - are often non-existent in national surveys, not eligible for public benefits, and unable to access fundamental human rights (Bowker \& Star, 2001; Waring, 2013). The empirical analysis of subjective exclusion-an inherently dynamic construct

\footnotetext{
2 We have extended Bourdieu's concepts of capital production and exchange to develop a conceptual model of social exclusion, as he did not apply his theory of social structures in this way. We have made every effort to preserve the integrity of Bourdieu's concepts and approach.
}

as it denotes process more than outcomes-measures the ability (or inability) to translate these personal assets into upward mobility. Subjective exclusion is evidenced when non-material (or symbolic) forms of capital (e.g., strong social networks, education, work experience, and language skills) are not readily transferred to material capital for certain social groups. For example, studies consistently report that people who are both immigrants and non-white are more likely to have lower incomes and wages, even after working in Canada for decades (Block \& Galabuzi, 2011; Pendakur $\&$ Woodcock, 2010). Foreign work experience, specifically from "non-traditional source countries", is decreasingly valued in the Canadian labour market (Aydemir \& Skuterud, 2005); and women do not cash in on education and credentials to the same extent as men (Boudarbat \& Connolly, 2013; Javdani, n.d.). In other words, individuals and groups may be denied access to all forms of capital, and even more cogent, the personal assets of those who hold small volumes of capital are afforded limited functional value in social exchanges. The making of kinds, or "group-making" (Bourdieu, 1985, 1987)-through the systematic dispossession and devaluing of material and symbolic forms of capital-is subjective exclusion, and it functions to keep people in place.

Each of the four forms of social exclusion is reported in discrete and sometimes incompatible or competing literatures. The concepts of SE/I permit the integration or transcendence of common disciplinary, methodological, and theoretical divides to examine intersections between forms of economic, spatial and socio-political exclusion that reinforce and self-sustain. Our theoretical framework shifts the familiar analytical and intervention focus from social exclusion as a category or kind of individual, to social exclusion as structures and dynamics that produce and organize groups in society. We propose a vantage point from which both the individual and the socialthe micro and the macro-are situated as simultaneous and interacting objects of study. Drawing on Bourdieu's methodological approach to the empirical analysis of social structures (see for example Bourdieu, 1984, 2005) we utilize a two-stage approach to secondary data analysis. First, we examine the relative outcomes and trajectories of individuals, groups, and communities in Canada's labour market. Second, we ask what these findings tell us about the social structures and dynamics of the labour market social field. The overarching objective of the three studies described below was to refine our conceptual model through developing and testing social exclusion and inclusion indicators and statistical models designed to demonstrate specific patterns of inequality and something of the social mechanisms by which such structures are reproduced. 


\section{Operationalizing the Concepts of Social Exclusion and Inclusion: A Case Example}

\subsection{Methodology}

Our indicators and statistical models are designed to both conduct comparative analyses of access to material and social assets in Canada's labour market and, subsequently, to trace the ability of individuals and groups to convert non-material assets (social and cultural) $^{3}$ into economic capital over time. Thus, we first briefly review our statistical findings in the traditional manner, focusing on significant differences between individual and group outcomes and trajectories. Then, we turn our analysis to social structures and dynamics. Following Bourdieu's lead, we use comparative analysis of our outcome variable to examine the distribution of economic and social resources in the labour market social field ("the structure of the field of production"), and the functional value of non-material assets for individuals and groups ("the mechanisms that determine its functioning") (Bourdieu, 2005, p. 17). For the three studies reported on below, we use secondary analysis of the micro data files of the Survey of Labour and Income Dynamics (SLID), a representative survey collected by the Canadian government that focuses on labour market activity and income for individuals and families. The SLID was selected because the longitudinal nature of the data and the large and representative sample size were instructive in our efforts to analyse the economic and social trajectories of individuals and groups over time.

\subsection{Developing Social Exclusion Measures}

\subsubsection{Our Independent Variables - Exploring the Making of Kinds}

In keeping with our theoretical lens, we operationalized individual attributes, such as immigrant status, ethnicity and "visible minority" status", age, and gender

\footnotetext{
${ }^{3}$ Acquired forms of capital are often termed "human capital", especially in political and economic discourse. Bourdieu (2005) refers to this as a "vague and flabby notion", "heavily laden with sociological unacceptable assumptions" (p. 2) such as the "cult of the individual and 'individualism"' (p. 11). As such, it is unable to shed light on the "economic common sense", or the "socially constructed, and hence arbitrary and artificial" moral view of the world (p. 10) that feeds the structures and dynamics of social exclusion.

4 The "visible minority" groupings were derived by Statistics Canada in 1991 in a multi-step process based on responses to questions on ethnic background, mother tongue and country of birth (Palameta, 2004). There is little or no evidence that this classification scheme corresponds to participants' selfidentification or the social world, nor has it been updated to
}

as vigorous yet shifting codes of differentiation and schemes of valuation, or "cognitive structures" (Bourdieu, 1989). We note that social categories commonly used in survey datasets (such as immigrant status and ethnicity/race) are conventionally simplistic and falsely dichotomous. We theorized that these common social classifications are not given or natural in the social world, but rather are produced through processes and practices of social exclusion that work to systematically deny and devalue material and symbolic assets and serve to justify divisions and distancegaps-between individuals and groups.

\subsubsection{Our Dependent Variable-Tracing Economic and Social Trajectories}

Aiming to demonstrate intersecting dynamics of social exclusion, we developed an Economic Exclusion Index as our explanatory measure to trace labour market outcomes and trajectories. Through our theoretical framework, our Economic Exclusion Index is not used as a single measure, but rather as an outcome (or dependent variable) that demonstrates all forms of social exclusion as they function in this social field. ${ }^{5}$ Preserving the multi-dimensional character of social exclusion, an index allowed us to include a range of material and social indicators simultaneously. Specifically, for example, our indicators measure not only material resources or assets held by individuals and households, but also the quality of their economic activity (i.e., job precarity) in order to examine both economic and social trajectories in Canada's labour market. Using this index as our dependent variable, we analysed labour market outcomes and trajectories by social attributes to compare the relative influence of non-material assets and attributes.

Our completed Economic Exclusion Index comprises nine dimensions derived from combinations of existing variables in the SLID. The Index was uniformly weighted, as we had no theoretical justification for weighting one dimension more heavily than the other. Our Index deliberately encompasses a wide range of variables to capture divergent aspects of the dynamics

reflect demographic changes over the past three decades. We also recognize the contested nature of the term "visible minority" (e.g. Woolley, 2013). We use the term here because it is the label used in the SLID dataset.

${ }^{5}$ We identify this as an Economic Exclusion Index because the focus on employment and income in the SLID dataset limits our analyses to labour market structures and dynamics, which are crucial to the economic form of social exclusion in employment-based social welfare systems. We nonetheless attempted to exploit the dataset for the purposes of developing a multidimensional social exclusion index, and we included indicators that measure access to both material assets and social goods in the labour market. 
of social exclusion, yet its Cronbach's alpha score of 0.76 demonstrated a sufficient level of internal consistency. Table 1 details the nine dimensions of our Index, including their level of measurement (individual, or at the economic family or household level), and their type of measurement (either scaled from 0-1 or dichotomous). We purposefully included variables measured at the economic family or household level as well as the individual level to capture a more complete picture of social exclusion, as research shows, for example, that household and personal finances often do not correspond due to gender inequality in families and cultures (Bennett, 2013).

Table 1. Economic exclusion index.

\begin{tabular}{|c|c|c|}
\hline Dimension & $\begin{array}{l}\text { Variable } \\
\text { Operationalization }\end{array}$ & $\begin{array}{l}\text { Level of } \\
\text { Measurement }\end{array}$ \\
\hline $\begin{array}{l}\text { 1. Individual } \\
\text { Wages }\end{array}$ & $\begin{array}{l}\text { Composite hourly } \\
\text { wages were below } \\
\text { the mean }\end{array}$ & Dichotomous \\
\hline $\begin{array}{l}\text { 2. Economic } \\
\text { Family Earnings }\end{array}$ & $\begin{array}{l}\text { Earnings were below } \\
\text { the mean }\end{array}$ & Scaled \\
\hline $\begin{array}{l}\text { 3. Household } \\
\text { Income }\end{array}$ & $\begin{array}{l}\text { After-tax income was } \\
\text { below the Low } \\
\text { Income Measure } \\
\text { (LIM) }\end{array}$ & Scaled \\
\hline $\begin{array}{l}\text { 4. Transfer } \\
\text { Income }\end{array}$ & $\begin{array}{l}\text { Major source of } \\
\text { income for the } \\
\text { economic family is } \\
\text { government } \\
\text { transfers }\end{array}$ & Dichotomous \\
\hline $\begin{array}{l}\text { 5. Home } \\
\text { Ownership }\end{array}$ & $\begin{array}{l}\text { Individual's dwelling } \\
\text { was not owned by a } \\
\text { family member }\end{array}$ & Dichotomous \\
\hline 6. Job Security & $\begin{array}{l}\text { Individual had non- } \\
\text { permanent } \\
\text { employment or was } \\
\text { not employed in the } \\
\text { labour force }\end{array}$ & Dichotomous \\
\hline $\begin{array}{l}\text { 7. Employment } \\
\text { Adequacy }\end{array}$ & $\begin{array}{l}\text { Hours worked for } \\
\text { pay by the individual } \\
\text { was less than full- } \\
\text { time }\end{array}$ & Scaled \\
\hline $\begin{array}{l}\text { 8. Multiple Job } \\
\text { Holdings }\end{array}$ & $\begin{array}{l}\text { Individual had } \\
\text { multiple jobs per } \\
\text { week where total } \\
\text { earnings were below } \\
\text { the mean }\end{array}$ & Scaled \\
\hline $\begin{array}{l}\text { 9. Non-Wage } \\
\text { Benefits }\end{array}$ & $\begin{array}{l}\text { Individual had a job } \\
\text { without a pension } \\
\text { plan or was not } \\
\text { employed in the } \\
\text { labour force }\end{array}$ & Dichotomous \\
\hline
\end{tabular}

The first five dimensions of the index comprise somewhat standard economic measures, examining several aspects of income. However, we distinguish, to the extent possible, the source of income-whether from labour market engagement or government transfers, allowing for a more nuanced analysis of income as a measure of economic exclusion. The final four dimensions measure non-income related aspects of labour market engagement, and aim to encompass aspects of precarious employment, such as job permanence, parttime employment, and job benefits (Kogawa, Troper, \& Wong, 2012; Vosko, Zukewich, \& Cranford, 2003). In all cases, each dimension was scored so that a higher number demonstrated greater exclusion, as our Index was measuring distance or trajectory disparities between groups.

\subsection{Measuring Intersecting Forms of Social Exclusion in Canada's Labour Market}

Below, we briefly outline selected findings for three distinct stages of our secondary data analysis, each of which we consider a crucial component of tracing and documenting the complexities and dynamics of the four forms of social exclusion in Canada. Our guiding research question was: What is the structure of unequal outcomes and trajectories in the Canadian labour market, and what are the mechanisms of social exclusion that work to produce them?

\subsubsection{Cross-Sectional Analyses}

Our initial efforts to measure social exclusion used descriptive statistics of the population and logistic regression to examine the influence of various attributes on economic and social outcomes in Canada's labour market. Controlling for years of schooling, our results demonstrate that gender, "visible minority" status, age, and length of stay in Canada were all strong predictors of economic outcomes and the quality of labour market engagement in 2009. For example, individuals in a household in which the major income earner was a woman, as well as recent immigrants to Canada (controlling for sex, "visible minority" status, time since immigration and years of schooling) had adjusted odds of being below the Low Income Measure ${ }^{6}$ at least 2.5 times greater than those in the associated reference category (i.e., being in a household in which the major income earner was male, or being Canadian-born) $(p<.05)$. As well, younger workers aged 18-29 had more than three times greater adjusted odds than individuals aged 30-49 to have earnings in the bottom quintile (roughly $\$ 12,300$ or less) $(p<.05)$. And individuals who identified as a racial minority had $40 \%$ greater adjusted odds of being unemployed over the long-term than non-visible minorities $(p<.05)$ (Lightman \& Good Gingrich, 2012).

\footnotetext{
${ }^{6}$ Statistics Canada calculated the Low Income Measure (LIM) as a dollar threshold that delineates low income in relation to the median income.
} 
Next, we used our Economic Exclusion Index to describe and compare labour market trajectories of four social groups or cohorts in Canada (racial minority immigrants, white immigrants, racial minority Canadianborn, and white Canadian-born individuals) from 19962010. Figure 1 shows the proportion of each social group represented in the most excluded quintile, or the relative number of individuals that scored in the top $20 \%$ of our Index. In brief, our analysis demonstrated that racialised groups (both immigrant and Canadian-born) were most likely to be among the most excluded $20 \%$ throughout this time period, while white immigrants experienced consistently better labour market outcomes than white Canadian-born. Over the 15 years examined, racial minority Canadian-born endured deteriorating trajectories (or increasing social exclusion) in the labour market, while social and economic trajectories for all other social groups remained generally stable.

These descriptive analyses reveal key features of the patterns and mechanisms of social exclusion by which the social structures of Canada's labour market are produced. Through our theoretical framework, the disparities in labour market trajectories of racialised cohorts (both immigrant and Canadian-born) demonstrate selective processes of economic exclusion (or the divestment of material capital, such as income and wages) as well as some evidence of subjective exclusion (or the systematic devaluation of non-material forms of capital, such as education). We subsequently pursued a deeper examination of the intersecting forms of social exclusion through longitudinal analysis.

\subsubsection{Growth Curve Analysis of Panel Data}

In our longitudinal study, we positioned social attributes (racial minority group, immigrant status, sex, age, and region of residence) as independent variables to test their influence on individual economic and social trajectories over time. Using multi-level modeling, we included non-material assets (such as years of schooling, mother tongue as a proxy for language proficien$\mathrm{cy}^{7}$, and self-reported health) as additional independent variables in our model, aiming to measure differential conversion rates of these holdings to economic capital and advancement over time. This study utilized the most recent six-year panel of the SLID to measure labour market trajectories of individuals from 2005-2010.

\footnotetext{
7 Improving language skills of immigrants has become a key "integration" strategy in Canada in recent years. Since the SLID dataset does not include variables to measure the effects of this form of cultural capital, we converted "mother tongue" into a dichotomous variable to indicate whether an individual's mother tongue was one of Canada's two official languages (English or French).
}

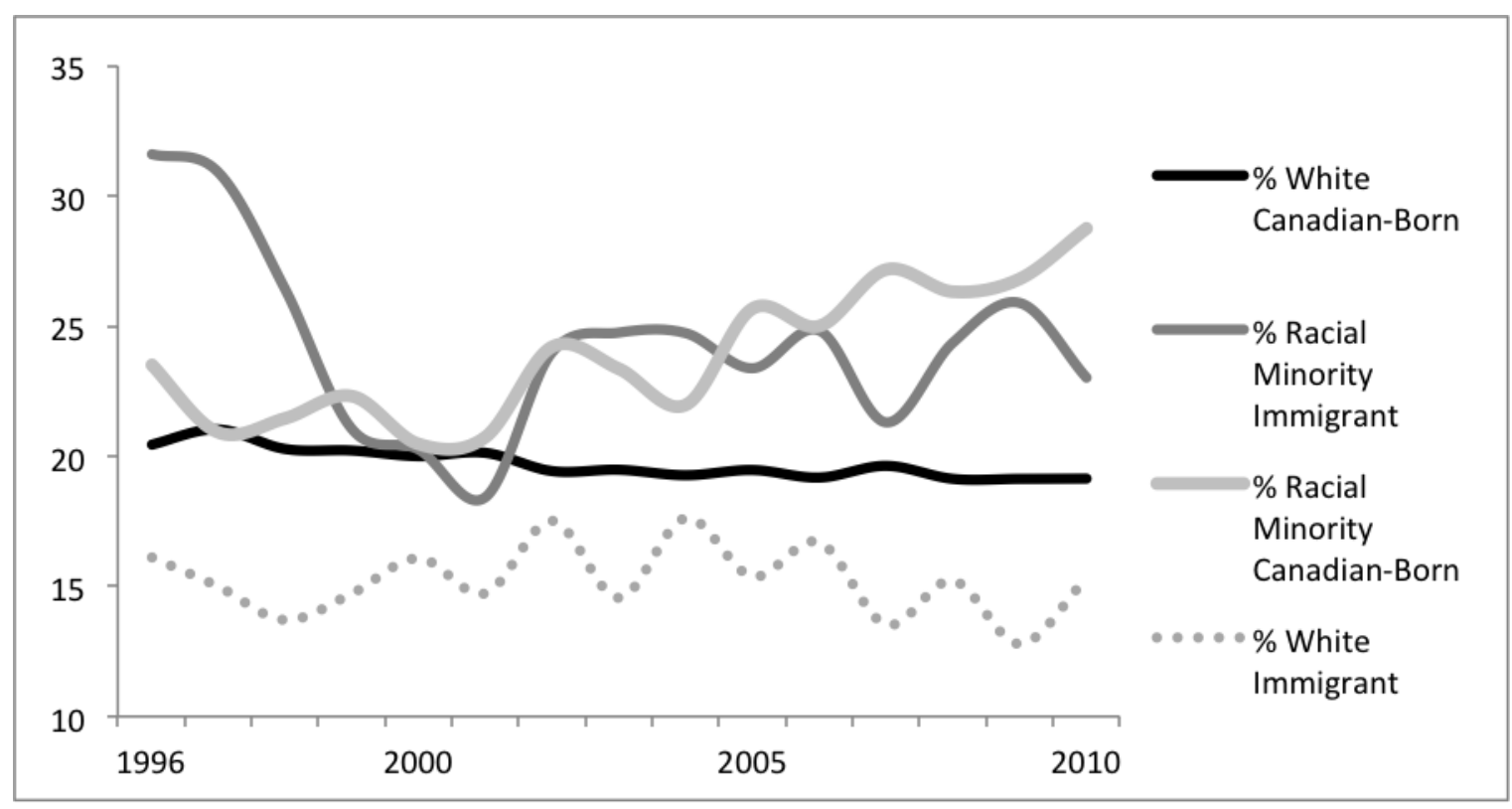

Figure 1. Representation of social groups by Top 20\% (most excluded) of Economic Exclusion Index. Note: As this is an index of economic exclusion (and not inclusion), higher numbers on the graph indicate a worse scenario and greater exclusion. 
Here, we found disparities among and within various groups of "visible minorities". Controlling for the social attributes and individual assets listed above, our results show that in 2005, at the beginning of the panel, Index scores relative to white individuals were more than 30 per cent higher for persons identified as Black, South Asian and Filipino, Japanese, Korean, Latin American and Oceanic. The entire population experienced a significant but very slight trajectory towards greater social exclusion during the course of the panel, with "Arab" individuals having a 50 per cent steeper trajectory toward increasing exclusion as compared to other groups. However, when compared with white individuals, trajectories for many racial minority group members (Black, Chinese, South East Asian, and South Asian) did not show significant change over time, indicating that those racialised groups who were relatively more excluded during the first year of the panel remained so over the course of the six-year survey. On its own, immigrant status (as a dichotomous variable) ${ }^{8}$, apart from membership in a racial minority group, was not a significant predictor of labour market outcomes or trajectories. All reported findings were significant at the $95 \%$ confidence level. ${ }^{9}$

From a structural vantage point, our findings reveal that social exclusion dynamics in the labour market field function more intensely and persistently for most racial minority persons than for white individuals, both initially and over time, and irrespective of social and cultural holdings. Although falsely blunt as a dichotomous variable, our finding of non-significance for immigrant status is consistent with our cross-sectional results, suggesting that the more decisive axis of differentiation for social exclusion dynamics is physical appearance and specific racial markers. The Canadian labour market is thus evidenced to limit upward mobility for certain racialised individuals, thereby reproducing and reinforcing its structure according to sociallycontrived racial/ethnic classifications. Furthermore, the model reveals that this social organization is achieved, at least in part, through the precisely unequal distribution of material and social resources in this social field. But more consequential, the data show uneven access to legitimate means of capital exchange and accumulation, whereby certain individuals are less able to translate their social and cultural assets into material capi-

\footnotetext{
8 In our growth model, we were unable to account for time since arrival in Canada due to inadequate sample sizes.

${ }^{9}$ Giving evidence to spatial exclusion, our findings show that individuals living outside of Ontario had higher Index scores than individuals residing in Ontario. These gaps diminished only marginally over the course of the panel. The dynamics of spatial exclusion may be more evident at the level of neighbourhoods or even buildings, but we were unable to parse to more specific geographic areas in our secondary data analysis due to inadequate sample sizes. We plan to further pursue this form of social exclusion in future research.
}

tal, thus thwarting conventional strategies for upward mobility. Specifically, our results show that the education, credentials, and language skills held by a person identified with certain "visible minority" categories do not have the same symbolic power or exchange value as the same volume of cultural capital held by a white person. We argue that this demonstrates that the functional value of non-material forms of capital depends primarily on the precise ethno-racial attributes of its holder, thus refuting market logic of individual responsibility and competition, and undermining the moral imperative of progressive upward mobility via education, training and labour market participation. Although "visible minority" categorizations are socially constructed, they are effectively made in social relations by way of precise patterns of capital divestment and devaluation that are real and measurable. This is the dispossession of symbolic power, or subjective exclusion.

\subsubsection{Analysis of Non-Response Rates}

Finally, progressing from our cross-sectional and longitudinal research findings, we note that the empirical measurement of any theoretical concept is both impeded and facilitated by the weaknesses and limits of the data. Thus, in our third study we investigated nonresponse rates of specific social groups in the SLID dataset and found revealing trends. In order to maintain measurement consistency, and because we had concerns about the accuracy of using data imputation methods, we elected to include data only for individuals who answered all questions in all dimensions of our Economic Exclusion Index. However, we subsequently ran an analysis of the same four social groups from our cross-sectional analysis (see Figure 2) to measure their relative rates of non-response on one or more dimensions of the Index. Notably, Figure 2 shows that rates of non-response appeared to increase for all social groups over the 15 year time period; by 2010, all groups besides the white Canadian-born had nonresponse rates on our Index indicators of over $50 \%$. Furthermore, it appears that, at least until the latter years of our analysis, all immigrants, regardless of racial minority status, were roughly $10 \%$ more likely not to respond to all dimensions of the Index than Canadian-born individuals. However, contradicting common explanations for low response rates that focus on cultural and language barriers for immigrants, we found that by the end of our analysis, Canadian-born racial minority individuals also show a marked increase in non-response.

A structural interpretation of these findings suggests that the same racialised social exclusion dynamics that result in outcomes of economic exclusion also make certain individuals and groups invisible. When combined with the divestment of material holdings, the nonrandom omission of individuals and groups 
from official datasets and discourse is evidence of the dispossession of social and cultural capital, or the socio-political form of social exclusion. Whole groups of people are thus made meaningless. Such invisibility is consequential, as it operates to reinforce all other forms of social exclusion.

Collectively, these three studies reveal that although much can be mined from secondary data analysis, no one quantitative inquiry can examine complex social dynamics in their totality. However, using our theoretical framework as a guide to our empirical work, we put forward these analyses as evidence of both the possibilities and the challenges inherent in the meaningful measurement of SE/I.

\section{Conclusions: Implications for the Development of Social Exclusion and Inclusion Measures}

We conclude with three recommendations for future research based on our review of existing SE/I research and our own efforts (as detailed above) to operationalize these complex ideas.

\subsection{Conceptual Clarity for Measuring SE/I-Assets and Attributes}

The distinction between assets and attributes reveals fundamental assumptions about the social world that are expressed in the design of statistical models. Personal holdings or assets (material and symbolic) can function as predictors (independent variables) or outcomes (dependent variables) of social exclusion. Typically, we do not conceive of attributes as resulting from social exclusion, and therefore they are included in statistical models only as predictors or independent variables. Yet the relationship between assets and attributes is often very close: for example, mother tongue is an attribute, but language proficiency is a cultural asset that can be acquired. Which has the most influence in the dynamics of social exclusion remains an important empirical question, as the distinction is critical for effective policy and service design. When social attributes are found to account for divergent economic outcomes and trajectories despite the volume of personal assets, the defining issue is demonstrated to be social value rather than individual quantity of personal holdings. This is the subjective form of social exclusion. Conventional policy and program interventions geared toward improving "employment readiness" and "labour market competitiveness" to foster social inclusion are designed to increase the volume of social and cultural capital, but will do little to address the functional quality of those assets. Ultimately, such common sense approaches form a regenerative feedback loop, reinforcing existing processes of social exclusion.



Figure 2. Non-response rates by social groups for one or more dimensions of the Index. 


\subsection{Methodological Issues for Measuring SE/I-Data and Datasets}

That which is not seen cannot be represented or measured, in quantitative or qualitative terms. Consequently, some researchers emphasize the need to develop new datasets and methodologies to study the most profound systems and effects of social exclusion (Bossert, D'Ambrosio, \& Peragine, 2007; Levitas et al., 2007). Stiglitz, Sen, and Fitoussi (2009), for example, stress that "policy-makers are reminded both of the richness and of the shortcomings of existing data but also of the fact that reliable quantitative information 'does not grow on trees' and significant investments need to be made to develop statistics and indicators that provide policymakers with the information they need to make the decisions confronting them" (p. 10). Thus, future efforts to foster social inclusion must recognize the need for greater representation and larger sample sizes of specific population groups, especially those at the upper and lower ends of social and economic spectrums; indicators that measure not only aggregate or average levels of social and material wellbeing, as is the inclination in quantitative research, but which more precisely and comprehensively identify social attributes and assets; and longitudinal data for the analysis of individual and household trajectories over time (Levitas et al., 2007). As a case in point, in our growth curve analysis detailed above, small sample sizes of some minority populations precluded the ability to disaggregate the findings at the level of neighborhoods, or even cities, drastically limiting our ability to measure spatial exclusion.

To date, efforts to "measure" and "know" the dynamics that make social groups-including people who are homeless, migrant workers, First Nations and Aboriginal peoples, incarcerated, unemployed, and working-but-still-poor individuals-are frequently inaccurate and partial, leaving public opinion about such groups to be shaped by preconceptions and "folk theories" (Bourdieu, 1989) that masquerade as fact and common sense. The limitations of existing national datasets are compounded in international comparisons, as the most dispossessed of the world often remain uncounted, or invisible. The more extreme the global divides between the "haves" and the "have nots", the less our ability to accurately reflect these social realities and understand the contributing social processes. People-even whole nations-are plunged into the obscurity and devaluation of social exclusion. The cogency of symbolic violence is evidenced by the paradoxical erasure of manufactured groups or kinds. Certain kinds are made invisible, even non-existent. Processes and practices of social exclusion are thus self-reinforcing and justified by conventional measurement systems that emphasize economic production over people's well-being (Stiglitz et al., 2009, p. 12). Ultimately, the development of "epistemic reflexivity" (Bourdieu, 1988), turning the analytical gaze back on the social dynamics of the research process itself, and research approaches that transcend quantitative, qualitative and theoretical research divides in academic and practice settings, are necessary to document intersecting macroand micro-level processes of exclusion and inclusion.

\subsection{Situating Social Exclusion and Inclusion-The Market System of Capital}

Social exclusion happens in a particular time and place (Byrne, 2005). Thus, the measurement of social exclusion must include analysis of the social structures or social field in which its dynamics are reproduced. The conception, measurement, and practice of social inclusion are similarly and necessarily specific to the social, economic, and political context that produced social exclusion in the first place. For example, the current Canadian government's preoccupation with the "integration" of immigrants "into Canada in a way that maximizes their contribution to the country" (Citizenship and Immigration Canada, 2012) is shown to be too narrow and off the mark. The government's key strategy toward this objective has been the careful selection of immigrants through Canada's points system, which restricts entry to those who are highly educated, proficient in one of two official languages, and have skillsets in demand in the Canadian labour force (Aydemir, 2011). Yet our analysis indicates that this policy approach is not effective in addressing processes of social exclusion defined by race. Specifically, for example, despite meeting these rather stringent criteria, racial minority immigrants (increasingly the majority among newcomers to Canada) see consistently lower rates of return on their investments (such as education, work experience, etc.) than white immigrants (Elrick \& Lightman, 2014). Moreover, Canadian-born visible minorities are similarly unable to realize comparable material gain from their social and cultural assets.

Our research, alongside a growing body of literature, demonstrates that the pervasive neoliberal approach to social welfare and its individual focus for both analysis and intervention is largely ineffective in addressing the inherent inequities of the market, as is the original and defining role of the welfare state. Situating the structure and dynamics of the Canadian labour market as the object of analysis, our quantitative studies of social exclusion reveal that popular "peoplechange" strategies of employment-based social welfare systems operate according to market ideals and values, or system of capital, to form a closed loop-a selfcontained and self-containing unit-that works to keep people in place (Good Gingrich, 2010). Market structures are necessarily uneven, as the unequal distribution of resources is key to a variety of profit-generating practices (Stiglitz, 2013). Insofar as the inequities of the 
market are produced by ideas and ideals of individualism, competition, and autonomy, the rules of capital exchange and accumulation that define effective social welfare systems must be rooted in alternative values, such as collectivity, cooperation, and shared responsibility. Policies and practices geared toward social inclusion, then, must shift in focus from economic (or social) integration of vulnerable individuals, to reorienting the system of capital that organizes the social welfare system.

To conclude, policy solutions to social exclusion commonly maintain a singular focus on personal assets (such as education and employment readiness), as social inclusion is most often equated with participation in the dominant social field and compliance to the market system of capital. A more meaningful conception of social inclusion must provide indicators for the analysis of individual and group mobility in the dominant social fields in which the rules for capital accumulation and exchange function to exclude. The measurement of SE/I must take into account intersections between individual-level characteristics and macrolevel factors to uncover alternative systems of capital that interrupt the self-reinforcing dynamics of social exclusion. Such research has real and measureable potential to inform transformative responses to reconcile divides within and among societies.

\section{Acknowledgements}

The authors wish to acknowledge the invaluable help of Andrew Mitchell and the assistance of Carmina Ng at the Statistics Canada Research Data Centre.

\section{Conflict of Interests}

The authors declare no conflict of interests.

\section{References}

Ades, J., Apparicio, P., \& Séguin, A.-M. (2012). Are new patterns of low-income distribution emerging in Canadian metropolitan areas. The Canadian Geographer, 56(3), 339-361.

Aldridge, H., Kenway, P., Maclnnes, T., \& Parekh, A. (2012). Monitoring poverty and social exclusion 2012. York, UK: Joseph Rowntree Foundation.

Atkinson, R. (2000). Combating social exclusion in Europe: The new urban policy challenge. Urban Studies, 37(5-6), 1037-1055.

Atkinson, T., Cantillon, B., Marlier, E., \& Nolan, B. (2002). Social indicators: The EU and social inclusion. Oxford: Oxford University Press.

Aydemir, A., \& Skuterud, M. (2005). Explaining the deteriorating entry earnings of Canada's immigrant cohorts, 1966-2000. Canadian Journal of Economics/Revue Canadienne d'Économique, 38(2), 641-672.
Bäckman, O., \& Nilsson, A. (2011). Pathways to social exclusion: A life-course study. European Sociological Review, 27(1), 107-123.

Bennett, F. (2013). Researching within-household distribution: Overview, developments, debates, and methodological challenges. Journal of Marriage and Family, 75(3), 582-597.

Block, S. (2010). Ontario's growing gap: The role of race and gender. In Growing Gap (pp. 1-14). Ottawa: Canadian Centre for Policy Alternatives.

Block, S., \& Galabuzi, G.-E. (2011). Canada's colourcoded labour market: The gap for racialized workers. Toronto: Canadian Centre for Policy Alternatives.

Bossert, W., D'Ambrosio, C., \& Peragine, V. (2007). Deprivation and social exclusion. Economica, 74(296), 777-803.

Boudarbat, B., \& Connolly, M. (2013). The gender wage gap among recent post-secondary graduates in Canada: A distributional approach. Canadian Journal of Economics/Revue Canadienne d'Économique, 46(3), 1037-1065.

Bourdieu, P. (1977). Outline of a theory of practice (R. Nice, Trans.). Cambridge: Cambridge University Press.

Bourdieu, P. (1984). Distinction: A social critique of the judgement of taste. Cambridge, MA: Harvard University Press.

Bourdieu, P. (1985). The social space and the genesis of groups. Theory and Society, 14(6), 723-744.

Bourdieu, P. (1987). What makes a social class? On the theoretical and practical existence of groups. Berkeley Journal of Sociology, 32, 1-17.

Bourdieu, P. (1988). Homo academicus (P. Collier, Trans.). Stanford, CA: Stanford University Press.

Bourdieu, P. (1989). Social space and symbolic power. Sociological Theory, 7(1), 14-25.

Bourdieu, P. (1990). The logic of practice (R. Nice, Trans.). Stanford, CA: Stanford University Press.

Bourdieu, P. (2005). The social structures of the economy. Cambridge: Polity Press.

Bowker, G. C., \& Star, S. L. (2001). Pure, real and rational numbers: The American imaginary of countability. Social Studies of Science, 31(3), 422425.

Byrne, D. S. (2005). Social exclusion (2nd ed.). Buckingham: Open University Press.

Citizenship and Immigration Canada. (2012). Our mandate, mission and vision. Retrieved from http://www.cic.gc.ca/english/department/mission. asp

Couturier, E.-L., \& Schepper, B. (2010). Who is getting richer, who is getting poorer: Quebec 1976-2006 (pp. 1-59). Ottawa: Canadian Centre for Policy Alternatives/Institut de Recherche et d'Informations Socio-Économiques.

Elrick, J., \& Lightman, N. (2014). Sorting or shaping? 
The gendered economic outcomes of immigration policy in canada. International Migration Review. doi:10.1111/imre.12110

Esping-Andersen, G., Gallie, D., Hemerijck, A., \& Myles, J. (2001). A new welfare architecture for Europe? Report submitted to the Belgian Presidency of the European Union.

European Commission. (1994). European social policy: A way forward for the Union, White Paper. Luxembourg: Office for Official Publications of the European Communities.

Farrington, F. (2001). Towards a useful definition: Advantages and criticisms of "social exclusion". Retrieved from http://www.ssn.flinders.edu.au/ geog/2002honours/farrington.php

Frenette, M., \& Morissette, R. (2003). Will they ever converge? Earnings of immigrant and Canadianborm workers over the last two decades. In Analytical Studies Branch research paper series (pp. 1-24). Ottawa: Statistics Canada.

Fuller, S., \& Vosko, L. F. (2008). Temporary employment and social inequality in Canada: Exploring intersections of gender, race and immigration status. Social Indicators Research, 88(1), 31-50.

Gilbert, N. L., Auger, N., Wilkins, R., \& Kramer, M. S. (2013). Neighbourhood income and neonatal, postneonatal and Sudden Infant Death Syndrome (SIDS) mortality in Canada, 1991-2005. Canadian Journal of Public Health, 104(3), 187-192.

Ginsburg, N. (1997). Housing. In A. Walker \& C. Walker (Eds.), Britain divided: The growth of social exclusion in the 1980's and 1990's (pp. 140-152). London: Child Poverty Action Group.

Giorgi, L., \& Pohoryles, R. J. (1999). Income analysis and social inclusion policies. Innovation, 12(4), 549-566.

Glennerster, H. (2000). US poverty studies and poverty measurement: The past twenty-five years. London: Centre for Analysis of Social Exclusion, London School of Economics.

Good Gingrich, L. 2003. Social exclusion as an individual kind: A categorical point of view. Canadian Review of Social Policy, Fall/Winter(52), 93-115.

Good Gingrich, L. 2006. Contesting social exclusion: An interrogation of its self-imposed expressions (PhD Thesis). Faculty of Social Work, University of Toronto, Toronto.

Good Gingrich, L. 2008. Social exclusion and double jeopardy: The management of lone mothers in the market-state social field. Social Policy \& Administration, 42(4), 379-395. doi:10.1111/j.1467-9515.2008. 00610.x

Good Gingrich, L. 2010. Single mothers, work(fare), and managed precariousness. Journal of Progressive Human Services, 21(2), 107-135. doi:10.1080/10428 230903301410

Good Gingrich, L. 2012. Negotiating double binds of inbetween: A gendered perspective of formal and in- formal social supports in transnationality. In A. Chambon, W. Schröer, \& C. Schweppe (Eds.), Transnational social support (pp. 81-107). New York: Taylor \& Francis/Routledge.

Hobcraft, J. (2000). The roles of schooling and educational qualifications in the emergence of adult social exclusion. London: Centre for Analysis of Social Exclusion, London School of Economics.

Hyman, I., Meinhard, A., \& Shields, J. (2011). The role of multiculturalism policy in addressing social inclusion processes in Canada. Toronto: Centre for Voluntary Sector Studies, Ryerson University.

Hyman, I., Mercado, R., Galabuzi, G.-E., \& Patychuk, D. (2011). A critical review of social exclusion and inclusion indicators: Implications for the development of a Canadian framework. In $\mathrm{K}$. Murphy Kilbride (Ed.), Immigrant integration: Research implications for future policy (pp. 85-102). Toronto: Canadian Scholars' Press Inc.

Javdani, M. (n.d.). Glass ceilings or glass doors? The role of firms in male-female wage disparities. Canadian Journal of Economics/Revue Canadienne d'Économique, forthcoming.

Johnston, L. (2013). It all begins with space: Maximizing use of public assets for engaged and healthier neighbourhoods in Toronto. Toronto: Social Planning Toronto.

Kerstetter, S. (2009). The affordability gap: Spending differences between Canada's rich and poor (pp. 117). Ottawa: Canadian Centre for Policy Alternatives.

Kim, A. H., \& Boyd, M. (2009). Housing tenure and condos: Home ownership by immigrant generations and the timing of arrival. Canadian Journal of Urban Research, 18(1), 47-73.

Kogawa, J., Troper, H., \& Wong, J. Y. K. (2012, May 6). Bill C-31: Past wrongs and present-day injustices. The Toronto Star.

Koti, F. T. (2010). Confronting sociospatial exclusion on the fringe of Africa's cities using participatory GIS: Lessons from Athi River Town, Kenya. Africa Today, 56(3), 62-82.

Lechman, E. (2013). Socio-economic exclusion as a hindrance of economic development. A comparative study for European countries (Working Paper Series A). Gdansk, Poland: GUT Faculty of Management and Economics.

Levitas, R., Pantazis, C., Fahmy, E., Gordon, D., Lloyd, E., \& Patsios, D. (2007). The multi-dimensional analysis of social exclusion (pp. 246). Bristol: University of Bristol.

Lightman, E. (2003). Social policy in Canada. Toronto: Oxford University Press.

Lightman, E., Herd, D., \& Mitchell, A. (2008). Precarious lives: Work, health, hunger among current and former welfare recipients in Toronto. Journal of Policy Practice, 7(4), 242-259.

Lightman, N., \& Good Gingrich, L. (2012). The 
intersecting dynamics of social exclusion: Age, gender, race and immigrant status in canada's labour market. Canadian Ethnic Studies, 44(3), 121-145.

MacLeavy, J. (2008). Neoliberalising subjects: The legacy of New Labour's construction of social exclusion in local governance. Geoforum, 39(5), 1657-1666.

Michalos, A. C., Smale, B., Labonté, R., Muharjarine, N., Scott, K., Moore, K., Swystun, L., Holden, B., Bernardin, H., Dunning, B., Graham, P., Guhn, M., Gadermann, A. M., Zumbo, B. D., Morgan, A., Brooker, A.-S., \& Hyman, I. (2011). The Canadian Index of Wellbeing. Waterloo, ON: Canadian Index of Wellbeing and University of Waterloo.

Munck, R. (2005). Globalization and social exclusion: $A$ transformationalist perspective. Bloomfield, CT: Kumarian Press.

Nolan, B., \& Whelan, C. T. (2010). Using non-monetary deprivation indicators to analyze poverty and social exclusion: Lessons from Europe? Journal of Policy Analysis and Management, 29(2), 305-325.

Osberg, L. (2008). A quarter centruy of economic inequality in Canada: 1981-2006 (pp. 1-46). Toronto: Canadian Centre for Policy Alternatives.

Palameta, B. (2004). Low income among immigrants and visible minorities. Perspectives on Labour and Income, 5(4), 12-17.

Pendakur, K., \& Woodcock, S. (2010). Class ceilings or glass doors? Wage disparity within and between firms. Journal of Business \& Economic Statistics, 28(1), 181-189.

Perri 6. (1996). Escaping poverty. London: Demos.

Pirani, E. (2013). Evaluating contemporary social exclusion in Europe: A hierarchical latent class approach. Quality \& Quantity, 47(2), 923-941.

Raphael, D. (2010). About Canada: Health and illness. Halifax, Nova Scotia: Fernwood Publishing.

Reitz, J. G., Banerjee, R., Phan, M., \& Thompson, J. (2009). Race, religion, and the social integration of new immigrant minorities in Canada. International Migration Review, 43(4), 695-726.

Reitz, J. G., \& Verma, A. (2004). Immigration, race, and labor: Unionization and wages in the Canadian labor market. Relations Industrielles/Industrial Relations, 43(4), 835-854.

Renahy, E., Alvarado-Llano, B., Koh, M., \& QuesnelVallée, A. (2012). Income and economic exclusion: Do they measure the same concept? International Journal for Equity in Health, 11(4), 1-11.

Roche, M. (2000). Comparative social inclusion policies and citizenship in Europe: Towards a new European social model. Final report. (pp. 1-157). Sheffield University, UK: Social Exclusion and Development of European Citizenship (SEDEC) Network, and Targeted Socio-Economic Research (TSER) Thematic Network.

Room, G. (1999). Social exclusion, solidarity, and the challenge of globalization. International Journal of Social Welfare, 8(3), 166-174.

Sen, A. (2000). Social exclusion: Concept, application, and scrutiny. Manila: Asian Development Bank.

Sin, R., \& Chung Yan, M. (2003). Margins as centres: A theory of social inclusion in anti-oppressive social work. In W. Shera (Ed.), Emerging perspectives on anti-oppressive practice (pp. 25-42). Toronto: Canadian Scholars' Press.

Smith, D. E. (1990). The conceptual practices of power: A feminist sociology of knowledge. Toronto: University of Toronto Press.

Spoor, M. (2013). Multidimensional social exclusion and the "rural-urban divide" in Eastern Europe and Central Asia. Sociologia Ruralis, 53(3), 139-157.

Stierle, F., Kaddar, M., Tchicaya, A., \& Schmidt-Ehry, B. (1999). Indigence and access to health care in subSaharan Africa. International Journal of Health Planning and Management, 14(2), 81-105.

Stiglitz, J. E. (2013). The price of inequality: How today's divided society endangers our future. New York: W. W. Norton \& Company, Inc.

Stiglitz, J. E., Sen, A., \& Fitoussi, J.-P. (2009). Report by the Commission on the measurement of economic performance and social progress (pp. 292). Paris, France: Commission on the Measurement of Economic Performance and Social Progress (CMEPSP).

Tibaijuka, A. K., \& Kaijage, F. (1995). Patterns and processes of social exclusion in Tanzania. In G. Rodgers, C. Gore, \& J. B. Figueiredo (Eds.), Social exclusion: Rhetoric, reality, responses (pp. 187-200). Geneva: International Institute for Labour Studies, ILO.

Veit-Wilson, J. (1998). Setting adequacy standards: How governments define minimum incomes. Bristol: Policy Press.

Vosko, L. F., Zukewich, N., \& Cranford, C. (2003). Precarious jobs: A new typology of employment. Perspectives on Labour and Income, 4(10), 16-26.

Walcott, R. (2014). In this moment: Thoughts on decoloniality, social justice and radical collectivities. Paper presented at the The International Day for the Elimination of Racial Discrimination Annual Lecture, School of Social Work, York University, Toronto.

Walker, W. M., \& Vajjhala, S. P. (2009). Gender and GIS: Mapping the links between spatial exclusion, transport access, and the Millennium Development Goals for Lesotho, Ehtiopia, and Ghana (RFF Discussion Paper). Washington, DC: Research for the Future. doi: http://dx.doi.org/10.2139/ssrn. 1473931. Retrieved from http://ssrn.com/abstract $=1473931$

Waring, M. (2013). Unpaid workers: The absence of rights. In M. Hobbs \& C. Rice (Eds.), Gender and women's studies in Canada: Critical terrain (pp. 90- 
98). Toronto: Women's Press.

Wilson, B., Lightman, E., \& Mitchell, A. (2009). Sick and tired: The compromised health of social assistance recipients and the working poor in Ontario. Toronto: Community Social Planning Council of Toronto; Wellesley Institute; SANE.

Woolley, F. (2013, June 10). "Visible minority": A misleading concept that ought to be retired. The Globe and Mail.

Yalnizyan, A. (2007). Ontario's growing gap: Time for leadership (pp. 1-40). Toronto: Canadian Centre for
Policy Alternatives.

Zhang, X. (2003). The wealth position of immigrant families in Canada (Analytical Studies Branch research paper series No. 197). Ottawa: Statistics Canada.

Zhao, J., Xue, L., \& Gilkinson, T. (2010). Health status and social capital of recent immigrants in Canada: Evidence from the Longitudinal Survey of Immigrants to Canada. In Research and Evaluation (pp. 1-29). Ottawa: Citizenship and Immigration Canada.

\section{About the Authors}
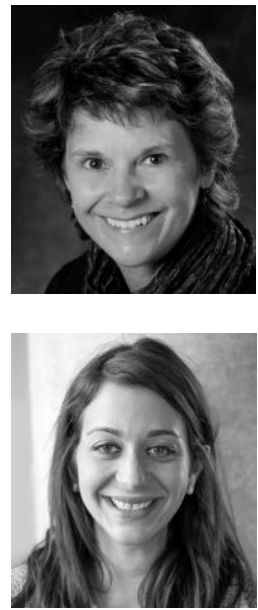

Dr. Luann Good Gingrich

Luann Good Gingrich is an Associate Professor in the School of Social Work at York University in Toronto, Canada. Her primary research interests are focused on the study of the processes and outcomes of social exclusion along intersecting axes of differentiation, such as race, class, gender, and religion. Her varied program of research uses qualitative methods and secondary data analysis to articulate how social environments work, tracing official structures, policies, and practices to the everyday and ordinary.

\section{Naomi Lightman}

Naomi Lightman is a SSHRC-funded PhD Candidate at the Ontario Institute for Studies in Education at the University of Toronto. Her thesis focuses on the implications of an increasingly transnational student milieu in the Greater Toronto Area secondary schooling context. Her research interests include: immigration and transnationalism, research methodology (quantitative and qualitative), social inequality, education policy, and sociology of education. Her academic work has been published in International Migration Review, Canadian Ethnic Studies and the Transnational Social Review-A Social Work Journal. 